EGU2020-10040

https://doi.org/10.5194/egusphere-egu2020-10040

EGU General Assembly 2020

(c) Author(s) 2020. This work is distributed under

the Creative Commons Attribution 4.0 License.

\title{
Structure and evolution of the Jan Mayen Microcontinent
}

\author{
Anke Dannowski ${ }^{1}$, Michael Schnabel ${ }^{2}$, Udo Barckhausen ${ }^{2}$, Dieter Franke², Martin Thorwart ${ }^{3}$, \\ Thomas Funck ${ }^{4}$, Martin Engels ${ }^{2}$, and Christian Berndt ${ }^{1}$ \\ ${ }^{1}$ GEOMAR Helmholtz Centre for Ocean Research Kiel, Marine Geodynamics, Kiel, Germany \\ ${ }^{2}$ BGR Federal Institute for Geosciences and Natural Resources (BGR), Hanover, Germany \\ ${ }^{3}$ Institute of Geosciences, Kiel University, Germany \\ ${ }^{4}$ Geological Survey of Denmark and Greenland (GEUS), Copenhagen, Denmark
}

The Jan Mayen Ridge (JMR) is a 150-km-long and 10-30 km wide seafloor expression in N-S direction in the centre of the North Atlantic and part of the Jan Mayen Microcontinent (JMMC). Previous studies show that the eastern flank of the JMR was formed during the breakup of the Norway Basin along today's Aegir Ridge, prior to magnetic anomaly C23 ( 50 Ma). The western margin of the JMMC is conjugate to East Greenland. Rifting gradually propagated northward, likely from Chron C21 ( 46 Ma) onward. Fan-shaped magnetic anomalies in the Norway Basin suggest that the JMMC must have rotated counter-clockwise. The JMR is likely underlain by continental crust. Volcanic flows have been observed within the sediments in the Jan Mayen Basin (JMB). While a relatively uniform upper crust was observed throughout the JMMC, the thickness of the lower continental crust varies significantly from up to $15 \mathrm{~km}$ below the JMR down to almost zero thickness towards the western part of the JMB. However, the character of the lower crust and the development of the conjugate East Greenland - JMMC margins during Oligocene are still disputed.

Here, we investigate the crustal structure of the JMMC using a new 265-km-long seismic refraction line crossing the JMMC at $69.7^{\circ} \mathrm{N}$ in E-W direction, which was acquired on board of RV Maria S. Merian during cruise MSM67. The profile consists of 30 ocean bottom seismometers (OBS) with a spacing of $9.5 \mathrm{~km}$. The dataset was complemented by on-board gravity measurements and a magnetometer array towed behind the vessel during shooting. The line extends from oceanic crust in the Norway Basin, across the microcontinent and into oceanic crust that formed at the presently active mid-oceanic Kolbeinsey Ridge. The magnetic profile shows old seafloor spreading anomalies in the east (likely anomaly $24, \sim 52 \mathrm{Ma}$ ), then low amplitude magnetic anomalies in the central portion of the profile, which are typical for many plutonic continental rocks. On the western part of the profile, high amplitude anomalies of younger oceanic crust (likely anomalies C5C trough $\mathrm{C6}, \sim 19-16 \mathrm{Ma}$ ) are recognized near the western termination of the JMB. The seismic velocity distribution and crustal thickness vary strongly along the profile, with velocities typical for oceanic crust at either end of the profile and a thickened crust $(12-13 \mathrm{~km})$ underneath the JMR. This suggests that the JMMC consists of thinned continental crust with a total width of $100 \mathrm{~km}$. 